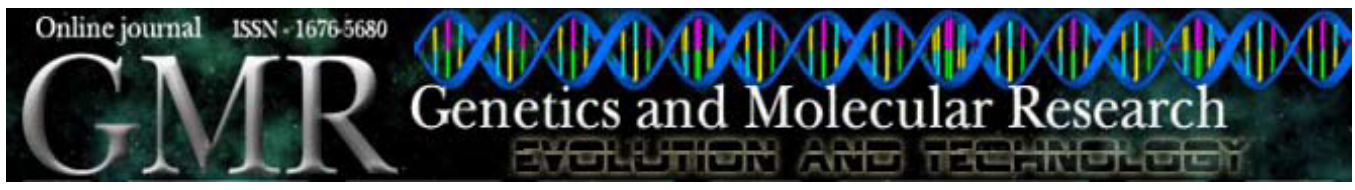

\title{
Structural evaluation of type 3 dopaminergic receptor gene (DRD3) in chronic anovulatory women
}

\author{
A.D.S. Santos ${ }^{1}$, R.A.A. Prado ${ }^{1}$, M.B. Melo ${ }^{2}$, M.R. Melo ${ }^{2}$ and C.A. Longui ${ }^{2}$ \\ ${ }^{1}$ Departamento de Ginecologia e Obstetrícia, Santa Casa de Misericórdia de \\ São Paulo, São Paulo, SP, Brasil \\ ${ }^{2}$ Laboratório de Medicina Molecular, Departamento de Ciências Fisiológicas, \\ Faculdade de Ciências Médicas da Santa Casa de São Paulo, São Paulo, SP, \\ Brasil \\ Corresponding author: A.D.S. Santos \\ E-mail: andrea.danielle@globo.com
}

Genet. Mol. Res. 7 (1): 140-151 (2008)

Received November 26, 2007

Accepted January 5, 2008

Published February 19, 2008

\begin{abstract}
Dopamine receptor type 3 (DRD3) expressed in the limbic system sites involved in the regulation of $\mathrm{GnRH}$ seems to play a role in neuroendocrine control. We hypothesized that women with chronic anovulation should show exacerbated secretion of prolactin (PRL) after thyrotropin-releasing hormone (TRH) stimulation test, having more chances for dopamine inhibitory dysfunction due to alterations in the structure of DRD3. The DRD3-coding region was evaluated in 60 women with chronic anovulation (35 without and 25 with hyperresponse of PRL after TRH stimulation), and in 34 controls. Statistically similar frequencies of homozygous AGC polymorphism (43.4 and 33.4\%) and heterozygous polymorphism (33.4 and 47.9\%) at position 9 were found in controls and patients, respectively. Homozygous GCG polymorphism at position 17 was identified in $3.4 \%$
\end{abstract}


of the patients, while heterozygosis occurred in $20.8 \%$ of the patients and in $6.6 \%$ of the controls. The novel $41563 \_41567$ delTAAGT polymorphism of DRD3 was identified in $14.7 \%$ of the controls and $8.6 \%$ of the women with chronic anovulation displaying hyperresponse of PRL after TRH stimulation. Alteration 41563_41567delTAAGT of DRD3 was not found in patients who did not show hyperresponse of PRL after TRH stimulation. Normal baseline and peak levels of PRL and thyroid-stimulating hormone were similar for women with and without 4156341567 delTAAGT in the DRD3 gene. It is concluded that the novel polymorphism in DRD3 identified in this study is not associated with the response of PRL to TRH stimulation in women with chronic anovulation.

Key words: Anovulation; Dopamine; Dopamine receptor type 3; Infertility

\section{INTRODUCTION}

Chronic anovulation is one of the most common causes of infertility and accounts for approximately $30 \%$ of the observed cases in our surroundings (Fernandes and Bahamondes, 1996), but higher rates are observed in developed countries (Frey and Patel, 2004). About $97 \%$ of anovulatory patients are classified in the WHO Group II which involves the presence of menstrual cycle disorders, including amenorrhea, evidence of endogenous estrogen production and normal serum concentration of follicle-stimulating hormone (FSH) and prolactin (PRL) (Fauser et al., 1991; ESHRE Capri Workshop Group, 1995; Taylor et al., 1997).

Hypothalamic gonadotropin-releasing hormone $(\mathrm{GnRH})$ secretion involves a series of monoaminergic system neurotransmitters showing stimulatory or inhibitory actions, mainly catecholamines, and among these, dopamine, whose action is predominantly inhibitory (Yen, 1979; Andersen et al., 1987), although it may exert a stimulatory effect, depending on its binding receptor (Rasmussen et al., 1986).

Dopamine is an important GnRH and PRL secretion inhibitor. Normal ovulation seems to be dopamine-dependent while irregular dopamine action may lead to the development of chronic anovulation. Two important observations are compatible with this hypothesis. The first one concerns the fact that one-third of these patients show either increased androgen secretions or mild hyperprolactinemia which may be explained by the presence of dopaminergic deficiency. The second observation is based on the knowledge that the syndrome is characterized by elevated luteinizing hormone (LH) secretion levels, and in some patients, dopamine infusion suppresses the increased LH secretion, thus also suggesting a relative dopaminergic deficiency (Kahsar-Miller et al., 1999).

The association of anovulatory states may be considered as a frequent cause of conjugal infertility together with neuroendocrine interaction abnormalities and dopamine's active participation - major factor in GnRH and PRL inhibition. Chronic anovulatory women displaying exacerbated PRL secretion in the thyrotropin-releasing hormone (TRH) stimulation test may have a higher possibility of dopamine-inhibitory dysfunction, even though having normal thyroid- 
stimulating hormone (TSH) serum levels. This catecholamine activity is developed within target cells by means of an interactive mechanism with its receptors.

The dopamine D3 receptor gene (DRD3) is expressed in the CNS limbic areas concomitant with the sites involved with GnRH regulation - either the modulator center of steroidogenesis and gametogenesis seems to be involved in this neuroendocrine control while structural changes in the dopamine D3-codifying gene could be related to chronic anovulation etiopathogenesis associated with PRL hyperresponse to TRH (Yen, 1979; Rasmussen et al., 1986; Taylor et al., 1997; Frey and Patel, 2004).

Several studies were able to identify the polymorphism in the DRD3 receptor gene as resulting from serine to glycine substitution at position 9 (Ser9Gly), particularly in schizophrenia cases (Dubertret et al., 1998; Williams, et al., 1998; Rybakowsky et al., 2001; Ioannidis et al., 2001). However, recent studies suggest that this is a very common genetic variation not connected to any pathological condition (Zhang et al., 2003; Jönsson et al., 2003; Staddon et al., 2005).

Other studies are still trying to identify eventual associations between DRD3 gene polymorphism and attention-deficit hyperactivity disorder (Muglia et al., 2002; DiMaio et al., 2003), arterial hypertension (Rice et al., 2002) and diabetic neuropathy (Pettersson-Fernholm et al., 2004), but up to now with inconclusive results.

It was specifically demonstrated that in anovulatory disorders observed in 130 women of Hispanic origin presenting chronic anovulation, the Ser9Gly D3 receptor gene homozygous polymorphism was associated with increased serum testotesterone levels and ovulatory dysfunction (Legro et al., 1995). Another study, including 248 non-Hispanic Caucasian women also investigated the eventual association between the D3 dopaminergic receptor and polycystic ovary syndrome. As no association of that kind could be found, the authors were led to conclude that although finding a dominant inheritance in this syndrome, the associated gene is yet to be correctly identified (Kahsar-Miller et al., 1999).

This study was intended to structurally evaluate the entire coding region of the DRD3 gene receptor in chronic anovulatory, normoprolactinemic women without hyperandrogenism in accordance with the prolactin TRH stimulation test.

\section{MATERIAL AND METHODS}

The present study was approved by our institutional Ethics Committee and all patients gave their written informed consent to participate in the study, which included 94 women attended by the Conjugal Infertility Ambulatory in the Obstetrics and Gynecology Department of "Irmandade da Santa Casa de Misericórdia de São Paulo", Brazil. Subjects were divided into control and study groups.

Control group included 34 women previously sterilized who sought the Gynecology Service to be submitted to sterilization reversal. Control women had a mean age of $30.8 \pm 5.8$ years, mean body mass index of $23.7 \pm 2.7 \mathrm{~kg} / \mathrm{m}^{2}$, and normal menstrual cycles (28- to 30-day intervals). The study group included 60 women with a diagnosis of chronic anovulation, no clinical or laboratory signs of adrenal and/or ovarian hyperandrogenism, normoprolactinemia, mean age of $25.7 \pm 4.5$ years and mean body mass index of $25.8 \pm 3.2$ $\mathrm{kg} / \mathrm{m}^{2}$; subjects had no clinical or laboratory signs of hypothyroidism, no pelvic tumors, and were not taking any medical drug likely to interfere with PRL levels. 
The exclusion criteria of the study group were galactorrhea, hirsutism (Ferriman and Gallway's score higher than 12), baseline PRL higher than $25 \mathrm{ng} / \mathrm{mL}, \mathrm{FSH}$ over 10 $\mathrm{mIU} / \mathrm{mL}$, clinical and/or laboratory signs of hyperandrogenism, and/or ovarian tumors, clinical and/or laboratory hypothyroidism, and hepatic and/or renal function alterations. Patients were excluded from the control group when showing plasma progesterone concentration levels lower than $6.5 \mathrm{ng} / \mathrm{mL}$, as established by the criterion of Speroff et al. (1999).

According to the WHO Group II classification, diagnosis of chronic anovulation is based on the clinical criterion of menstrual irregularity since the onset of menarche. Following anamnesis and complete physical and gynecological examinations, all subjects were submitted to determination of serum progesterone, testosterone, PRL, FSH and LH, TSH, T3 and T4. Subjects were also submitted to the stimulation test using an intravenous bolus injection of $200 \mu \mathrm{g}$ TRH. Control group patients were submitted to this test during the menstrual cycle median follicular phase (between the 5th and 8th days). The chronic anovulation group underwent the same tests at any day during the amenorrhea period. After phlebotomy, the scalp was maintained and patients were asked to remain resting for 15 min before the initial sample collection. No case of loss of venous access was observed. Blood samples were collected at the beginning of stimulation (baseline), and at 15, 30, and 45 min.

After TRH stimulation tests, patients were divided into two groups in accordance with the PRL peak response. Based on the 75th percentile of PRL peak concentrations - $63.05 \mathrm{ng} /$ $\mathrm{mL}$ - observed in the control group, 35 anovulatory women were classified as without hyperresponse of PRL (PRL values lower than $63.05 \mathrm{ng} / \mathrm{mL}$ ) and 25 women with hyperresponse of PRL (PRL values higher than cut-off values).

\section{Blood collection and DNA extraction}

After the withdrawal of $3 \mathrm{~mL}$ of peripheral blood into a tube containing EDTA, the material was submitted to DNA extraction using the method of Lahiri and Numberger Jr. (1991) modified by Cavalli et al. (1996) and Salazar et al. (1998).

DNA samples were extracted from the study group patients in order to evaluate the DRD3 gene's structural alterations. If alterations were found, the frequency of each case was compared to the results obtained in the control population of the same region.

\section{Molecular evaluation of the DRD3 gene}

\section{Polymerase chain reaction}

In order to amplify the codifying region and that of the DRD3 gene intron/exon limits (NM 000796, GenBank), eight pairs of primers were synthesized by the computer program "Primer 3 Input" (available at www.broad.mit.edu/cgi-bin/primer3_www.cgi). The gene comprises seven exons and the DRD3 gene-codifying region is composed of the last six exons; however, exons 2 and 6 are divided into two fragments. Mutations were screened using the singlestrand conformation polymorphism (SSCP) method. Evaluation of fragments showed varying sizes, from 219 to 285 bp and identified as 2B, 3, 4, 5, 6A, 6B, and 7 (Table 1). 


\begin{tabular}{|c|c|c|c|}
\hline Primer & Sequence - $5^{\prime} \rightarrow 3^{\prime}$ & $\mathrm{bp}$ & $\mathrm{Tm}$ \\
\hline $\begin{array}{l}2 \mathrm{As} \\
2 \mathrm{Aas}\end{array}$ & $\begin{array}{l}\text { TTCTGTCTCCTCACAGGAAGC } \\
\text { CTTCAGCACAGCCATGCAC }\end{array}$ & 219 & 57 \\
\hline $\begin{array}{l}\text { 2Bs } \\
\text { 2Bas }\end{array}$ & $\begin{array}{l}\text { CATCCTGGCCATCGTCGTCTTC } \\
\text { GTCTGGGGAGTCTTTTGAGC }\end{array}$ & 248 & 60 \\
\hline $\begin{array}{l}\text { 3s } \\
\text { 3as }\end{array}$ & $\begin{array}{l}\text { CTGGGTTGTCGTTCCTTCAC } \\
\text { ACCCTCAAGTGCACAATCTG }\end{array}$ & 245 & 60 \\
\hline $\begin{array}{l}4 \mathrm{~s} \\
4 \mathrm{as}\end{array}$ & $\begin{array}{l}\text { TCCATCTCACCATGCCTATC } \\
\text { AGTCATTCAGCTGTGCTGTG }\end{array}$ & 243 & 60 \\
\hline $\begin{array}{l}5 \mathrm{~s} \\
5 \text { as }\end{array}$ & $\begin{array}{c}\text { CTTGCTAACTGCTTTACCTTCC } \\
\text { AGTCAGGAGATTGGGTGTTG }\end{array}$ & 285 & 60 \\
\hline $\begin{array}{l}\text { 6As } \\
\text { 6Aas }\end{array}$ & $\begin{array}{l}\text { CCCCAGAAATGTCAAGATTC } \\
\text { TCTGCCATTGCTGAGTTTTC }\end{array}$ & 231 & 60 \\
\hline $\begin{array}{l}\text { 6Bs } \\
6 \mathrm{Bas}\end{array}$ & $\begin{array}{l}\text { TCCCTGAGTCCCACCATAG } \\
\text { GCATCTTCTACCAGCTCCAC }\end{array}$ & 229 & 60 \\
\hline $\begin{array}{l}7 \mathrm{~s} \\
7 \text { as }\end{array}$ & $\begin{array}{c}\text { AGTAAGCAAATCCCTTACCC } \\
\text { CAGCTAGAAATGGGTACAAAGAG }\end{array}$ & 285 & 60 \\
\hline
\end{tabular}

bp: amplified fragment size in base pairs; Tm: melting temperature for each pair of primers (in degrees Celsius).

Polymerase chain reaction (PCR) was employed with $0.7 \mu \mathrm{L}$ of each primer (Life Technologies do Brasil Ltda., 20 pmol/ $\mu \mathrm{L}$ ), $3 \mu \mathrm{L}$ 10X buffer (GeneAmp PCR Reagent Kit, Applied Biosystems), $0.9 \mu \mathrm{L} \mathrm{MgCl}_{2}(50 \mathrm{mM}), 1 \mu \mathrm{L}$ nucleotide mixture $(10 \mathrm{mM})$ and $0.1 \mu \mathrm{L}$ Taq DNA polymerase (5 U/ $\mu \mathrm{L})$ (Invitrogen, Carlsbad, CA), added to $1 \mu \mathrm{L}$ genomic DNA (100 $\mathrm{ng} / \mu \mathrm{L}$ ). The final PCR volume was $30 \mu \mathrm{L}$. After an initial denaturation at $94^{\circ} \mathrm{C}$ for $5 \mathrm{~min}$, samples were submitted to 35 cycles of denaturation at $94^{\circ} \mathrm{C}$ for $1 \mathrm{~min}$, annealing at $60^{\circ} \mathrm{C}$ for fragments $2 \mathrm{~B}, 3,4,5,6 \mathrm{~A}, 6 \mathrm{~B}$, and 7 for $1 \mathrm{~min}$, and extension at $72^{\circ} \mathrm{C}$ for $1 \mathrm{~min}$, followed by a final extension cycle at $72^{\circ} \mathrm{C}$ for $7 \mathrm{~min}$. The process was similar to that with $57^{\circ} \mathrm{C}$ as the annealing temperature for the $2 \mathrm{~A}$ fragment (GeneAmp9700, Applied Biosystems).

\section{Mutation screening using the single-strand conformation polymorphism}

Mutations were identified by the SSCP method (Sekiva, 1993; DiMaio et al., 2003). Electrophoresis were carried out on polyacrylamide gels with 4 to $20 \%$ concentration gradients in a Tris-borate-EDTA buffer, with run temperatures of $12^{\circ} \mathrm{C}$ for $2 \mathrm{~A}$ and $6 \mathrm{~B}$ regions, and $15^{\circ} \mathrm{C}$ for the remaining regions.

The presence of fragment alterations determined an anomalous secondary structure able to modify the gel-immersed sample migration pattern when compared to the control fragment, thus allowing for the technique to be used as a screening process.

\section{Automated sequencing}

Samples showing an altered electrophoretic mobility pattern detected by SSCP were submitted to automated sequencing. The samples were then amplified, purified, and submitted to the DNA-ABI Prism 310 (Applied Biosystems) automatic sequencing analyzer by the Big Dye Terminator Cycle Sequencing Ready Reaction Kit (Applied Biosystems) based on manu- 
facturer instructions. In the presence of alterations, each frequency was estimated by the same region analysis and also carried out in the control population.

\section{Statistical analysis}

The results obtained enabled us to identify both study and control group patients with DRD3 genetic alterations; alteration frequencies were compared using the chi-square test. Results were analyzed in relation to laboratory PRL parameters (mean \pm standard deviation) and baseline and peak TSH. The F test and the Student $t$-test were used to determine both groups' variance values and compare the medians, respectively. A 95\% confidence interval was adopted for all the applied tests, and significant differences were considered when the estimated $\mathrm{P}$ value was lower than 0.05 .

\section{RESULTS}

\section{Region 2 sequencing}

Investigations on DRD3 gene structural alterations using PCR-SSCP techniques showed a highly variable pattern of electrophoretic mobility in the $2 \mathrm{~A}$ region when compared to the control group. Selection difficulties made it necessary for both study and control groups to be submitted to the sequencing of this region. Both groups showed different genotypes at DRD3 gene positions 9 and 17 (Table 2), but no differences concerning their frequencies could be observed between the groups.

\begin{tabular}{|c|c|c|c|c|c|c|c|c|}
\hline \multirow[t]{3}{*}{ Genotype } & \multicolumn{4}{|c|}{ Position 9} & \multicolumn{4}{|c|}{ Position 17} \\
\hline & \multicolumn{2}{|c|}{ Study group } & \multicolumn{2}{|c|}{ Control group } & \multicolumn{2}{|c|}{ Study group } & \multicolumn{2}{|c|}{ Control group } \\
\hline & $\mathrm{N}$ & $\%$ & $\mathrm{~N}$ & $\%$ & $\mathrm{~N}$ & $\%$ & $\mathrm{~N}$ & $\%$ \\
\hline $\begin{array}{l}\text { Normal homozygote } \\
\text { (GGC/GCA) }\end{array}$ & 9 & 18.7 & 7 & 23.2 & 38 & 79.2 & 27 & 90.0 \\
\hline $\begin{array}{l}\text { Polymorphic homozygote } \\
\text { (AGC/GCG) }\end{array}$ & 16 & 33.4 & 13 & 43.4 & 0 & 0 & 1 & 3.4 \\
\hline Heterozygote & 23 & 47.9 & 10 & 33.4 & 10 & 20.8 & 2 & 6.6 \\
\hline Total & 48 & 100.0 & 30 & 100.0 & 48 & 100.0 & 30 & 100.0 \\
\hline
\end{tabular}

Position 9: study group vs control group; degrees of freedom: 2; critical chi-square: 5.79; estimated chi-square: $1.97(\mathrm{P}=0.05)$.

Position 17: study group vs control group; degrees of freedom: 2; critical chi-square: 5.79; estimated chi-square: $3.93(\mathrm{P}=0.05)$.

\section{Region 6B sequencing}

Investigations concerning DRD3 gene structural alterations using PCR-SSCP techniques showed that in the anovulatory group of PRL-hyperresponsive women, seven cases showed altered electrophoretic patterns; the samples were then submitted to direct sequencing in order to identify the possible alterations. Five cases were found in the PCR $6 \mathrm{~B}$ region and 
two in the 7 region. Three $6 \mathrm{~B}$ region samples showed the deletion in five bases (TAAGT) in one of the DNA strands (heterozygosis), thus characterizing a frameshift type mutation at the intron 7 initiation using the primer sense. The remaining samples failed to show structural alterations in this segment. This alteration, designated as 41563_41567delTAAGT, was also identified in five control group women. Figure 1 shows the automatic sequencing reaction chromatogram illustrating 41563_41567delTAAGT.

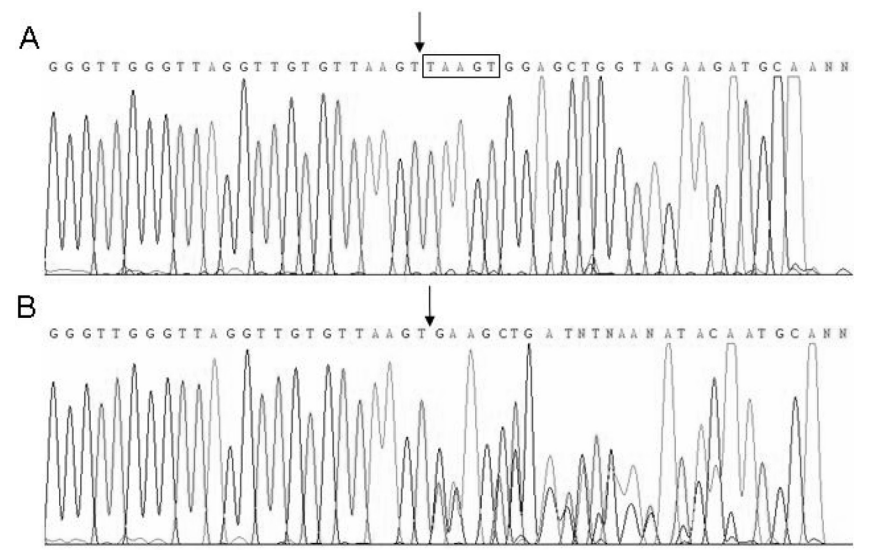

Figure 1. Sequencing of polymerase chain reaction product consistent with exon 6 and DRD3 gene adjacent regions. A. Normal individual. B. Patient showing deletion of five bases during sequencing. TAAGT/arrow indicated site. Frame-enhanced, deleted bases may be seen in $A$.

Alterations located between border regions of introns and exons could jeopardize the total RNA processing in mRNA and as a consequence, interfere in its translation and in the codified protein synthesis. This was the reason which led us to submit both normal and altered gene sequences to an analysis of alternative RNA processing sites, using the NetGene2 program (available at http://www.cbs.dtu.dk/services/NetGene2). This evaluation suggests the creation of a new splicing acceptor site within exon 6 in the presence of the deletion, with the maintenance of original sites (Figure 2).

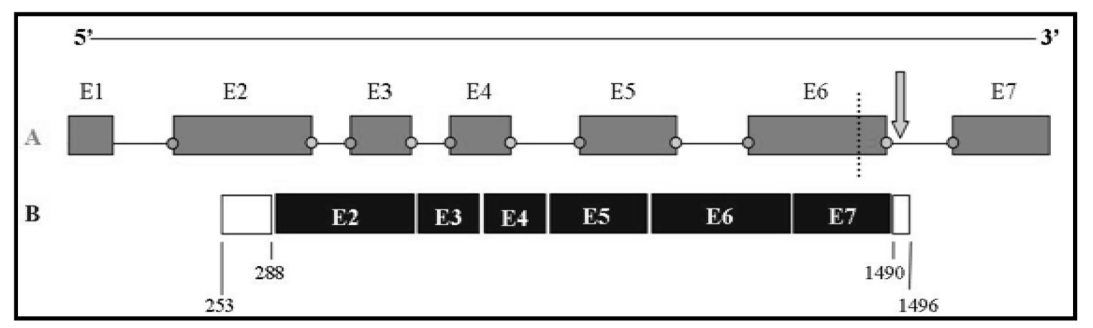

Figure 2. DRD3 gene representation organization. A. DRD3 gene located on the 3q13.3 chromosome. Lines represent introns and red boxes are representative of exons (E1 to E7). Yellow and green circles represent donor sites and acceptors involved in the splicing acceptor, respectively. The gray arrow represents intron 7 (TAAGT) deletion site. B. mRNA representation between 253 and 1496 nucleotides. The blue box represents the codifying region (CDS) between nucleotides 288 and 1490. Since there is no formation of a new donor site in exon 6 in order to become involved with an alternative processing with formed acceptor site, theoretically, no alternative structure of mRNA exists. 
Data analysis demonstrated that DRD3 gene 41563_41567delTAAGT in five control women $(14.7 \%)$ and in three anovulatory women (8.6\%) without PRL hyperresponse comprised the frequency of $8.5 \%$ in the total sample. None of the anovulatory PRL-hyperresponse women showed this genetic alteration. No significant difference could be observed in case frequency in each group in relation to the presence of 41563_41567delTAAGT in the DRD3 gene $($ chi-square $=4.16 ; \mathrm{P}>0.05)$.

\section{Laboratory parameters and polymorphism 41563_41567delTAAGT in the DRD3 gene}

Table 3 shows the laboratory parameters used to determine mean plasma values in each group. No significant difference was seen in the laboratory parameters studied related to the subdivided control group based on the presence of 41563_41567delTAAGT, with the exception of baseline PRL concentrations which were shown to be significantly $(\mathrm{P}=0.0318)$ lower in women with this polymorphism in the DRD3 gene $(4.7 \pm 0.6 \mathrm{ng} / \mathrm{mL})$ when compared to women without this alteration $(11.3 \pm 5.1 \mathrm{ng} / \mathrm{mL})$. In the anovulatory women who were PRL hyperresponse to TRH stimulation, no difference was observed for the parameters studied.

Table 3. Mean values \pm standard deviation of laboratory parameters (baseline and after thyrotropin-releasing hormone stimulation test) in the control group and chronic anovulatory women.

\begin{tabular}{|c|c|c|c|}
\hline & $\begin{array}{l}\text { Control women } \\
\qquad(\mathrm{N}=34)\end{array}$ & $\begin{array}{l}\text { Anovulatory women without } \\
\text { hyperresponse of PRL } \\
\qquad(\mathrm{N}=35)\end{array}$ & $\begin{array}{l}\text { Anovulatory women with } \\
\text { hyperresponse of PRL } \\
\qquad(\mathrm{N}=25)\end{array}$ \\
\hline Baseline TSH $(\mu \mathrm{IU} / \mathrm{mL})$ & $3.0 \pm 0.6$ & $2.5 \pm 1.1$ & $3.3 \pm 1.2$ \\
\hline Maximum TSH $(\mu \mathrm{IU} / \mathrm{mL})$ & $20.7 \pm 8.3$ & $18.7 \pm 9.5$ & $29.0 \pm 13.4$ \\
\hline Baseline PRL (ng/mL) & $10.6 \pm 5.1$ & $9.0 \pm 3.5$ & $17.3 \pm 5.5$ \\
\hline Maximum PRL (ng/mL) & $57.4 \pm 12.8$ & $41.3 \pm 11.7$ & $87.9 \pm 24.6$ \\
\hline Baseline LH $(\mu \mathrm{IU} / \mathrm{mL})$ & $5.2 \pm 1.7$ & $5.7 \pm 3.3$ & $4.3 \pm 2.5$ \\
\hline Baseline FSH $(\mu \mathrm{IU} / \mathrm{mL})$ & $5.9 \pm 2.0$ & $4.8 \pm 2.0$ & $4.6 \pm 2.0$ \\
\hline Progesterone $(\mathrm{ng} / \mathrm{mL})$ & $10.6 \pm 1.9$ & $2.7 \pm 1.3$ & $2.9 \pm 1.3$ \\
\hline $\mathrm{T} 3$ (ng/dL) & $132.9 \pm 18.3$ & $134.6 \pm 25.1$ & $139.5 \pm 26.5$ \\
\hline $\mathrm{T} 4(\mu \mathrm{g} / \mathrm{dL})$ & $8.3 \pm 1.6$ & $7.3 \pm 1.8$ & $7.8 \pm 1.8$ \\
\hline
\end{tabular}

$\mathrm{PRL}=$ prolactin; $\mathrm{TSH}=$ thyroid-stimulating hormone; $\mathrm{LH}=$ luteinizing hormone; $\mathrm{FSH}=$ follicle-stimulating hormone.

Control and anovulatory women without hyperresponse were treated as a single group and comparisons between them were based on this polymorphism presence or absence in the DRD3 gene; baseline TSH values were shown to be significantly $(\mathrm{P}=$ $0.0196)$ higher in women with this polymorphism $(3.5 \pm 0.9 \mu \mathrm{IU} / \mathrm{mL})$ than in those lacking this alteration $(2.7 \pm 0.9 \mu \mathrm{IU} / \mathrm{mL})$; no significant differences were observed in the remaining parameters evaluated.

When statistically comparing women showing or not 41563_41567delTAAGT in the DRD3 gene, it was observed that either baseline PRL levels (with polymorphism $=7.7 \pm 3.6$; no polymorphism $=12.1 \pm 5.8 \mathrm{ng} / \mathrm{mL} ; \mathrm{P}=0.0351$ ) or peak $\mathrm{PRL}$ values (with polymorphism $=44.9 \pm 17.2 ;$ no polymorphism $=0.9 \pm 24.8 \mathrm{ng} / \mathrm{mL} ; \mathrm{P}=0.0115$ ) were significantly lower in women showing DRD3 alterations. The whole group of women studied showed PRL basal values within the reference range. 


\section{DISCUSSION}

The present study was based on the following major pillars. 1) Dopamine plays a significant role as the main inhibitory substance of PRL secretion, and it influences the neuroendocrine phenomena regulating the ovulation process (Andersen et al., 1987; Knoepfelmacher, 1988; Cooper et al., 1991); 2) Dopaminergic D2 receptor agonist drugs have been effective in hyperprolactinemia control (Verhelst et al., 1999; Moro et al., 2001); 3) Evidence shows that D3 dopaminergic receptor (DRD 2 subfamily which enables the inhibition of adenyl cyclase) is expressed in the brain's limbic areas associated with cognition, emotion, and endocrine functions, particularly in regard to the regulation of GnRH secretion (Sokoloff et al., 1990; Sibley and Monsma Jr., 1992); 4) Preliminary studies have shown that homozygotic polymorphism seen in DRD3 gene seems to be associated with an ovulatory dysfunction (Legro et al., 1995).

Hypothetically, the DRD3 gene structural alterations could be associated with chronic anovulation conditions, especially those characterized by PRL hyperresponse after the TRH stimulation test, since dopamine participates as the main neuroendocrine catecholamine, representative of this circuit inhibition pathway.

Thus, DNA of 34 control and 60 chronic anovulatory women was analyzed. From the totality of subjects, 25 showed PRL hyperresponse after TRH stimulation test. The literature fails to report any study regarding the influence of the DRD3 gene in patients with similar hormonal characteristics, thus suggesting some deficiency in their dopaminergic mechanism. Our methodological approach evaluating the complete coding region of DRD3 gene using PCR-SSCP followed by automated sequencing is more informative than the usual targeted evaluation of DRD3 gene polymorphisms.

DRD3 gene analysis enabled the identification of polymorphisms at both the 9 and 17 positions, with no significant differences between observed frequencies in either control or the groups studied.

Regarding position 9, Ser9Gly polymorphism was identified in the DRD3 gene of $33.4 \%$ anovulatory and $43.4 \%$ control women. Heterozygotic polymorphism was also observed in $33.4 \%$ of the control group and $47.9 \%$ of the anovulatory women. These results are consistent with several authors' findings suggesting the existence of some type of association between DRD3 gene alterations and schizophrenia (Legro et al., 1995; Williams et al., 1998; Rybakowsky et al., 2001; Staddon et al., 2005).

Rybakowsky et al. (2001) observed Ser9Gly homozygotic polymorphism in the DRD3 gene in $61 \%$ of their subjects, and also in $30 \%$ of control samples, all of them showing eye movement disturbances typical of the presence of schizophrenia. Zhang et al. (2003) evaluated two subgroups of Chinese schizophrenic patients with the first subgroup consisting of 42 with persistent tardive dyskinesia and the second with 59 schizophrenic patients without dyskinesia. Ser9Gly heterozygotic polymorphism in the DRD3 gene was observed in $53 \%$ of the dyskinetic patients and in $33 \%$ of those without dyskinesia. Both studies suggested that those polymorphisms could be related to the investigated cases.

In order to explain the role played by DRD3 gene alterations in schizophrenia etiology, Staddon et al. (2005) carried out evaluations on three genetic variations (Ser9Gly, -205-G/A and $7685-\mathrm{G} / \mathrm{C}$ ) in 118 schizophrenic patients and 162 control subjects. The results failed to show any association between the disease and Ser9Gly and -205-A/G polymorphisms; however, this association was disclosed in $-7685-\mathrm{G} / \mathrm{C}$. 
The absence of significant differences when comparing control and anovulatory women regarding DRD3 gene polymorphism seems to corroborate the findings of Jönsson et al. (2004) and Staddon et al. (2005), suggesting that this is a common alteration, probably dissociated from any pathological process.

Investigations have identified some type of DRD3 gene polymorphisms (Sokoloff et al., 1990; Sibley and Monsma Jr., 1992; Williams et al., 1998; Rybakowsky et al., 2001), particularly those associated with ovulatory disorders (Legro et al., 1995; Kahsar-Miller et al., 1999). However, no references have been made to the 41563_41567delTAAGT alterations observed in the present study.

Deletion of five bases (TAAGT) in one of the DNA strands at the intron 7 initiation, would enable the creation of a new splicing acceptor site at exon 6. It must be emphasized that although absent, a new donor site could conjointly participate in the mRNA processing with that new acceptor site. If confirmed, this alteration could interfere in mRNA translation and as a consequence, affect either structurally or functionally the DRD3 gene-codified protein.

However, programs used for the mRNA processing prediction are based on algorithms that can only indicate relative probabilities of the predicted boundaries. This hypothesis validation depends on cDNA sequence analysis. Since the cDNA includes regions related to exons, which as a consequence will be linked to the codified protein, the eventually involved gene product could be evaluated by this analysis (Snyder and Stormo, 1993; Mathé et al., 2002). As recent patients' alteration samples were unavailable, the study could not be adequately completed. DRD3 gene 41563_41567delTAAGT alteration was present in $8.5 \%$ of the total sample. This frequency was $14.7 \%$ among the control group women and $8.6 \%$ in the anovulatory group showing PRL hyperresponse after TRH stimulation. No anovulatory woman with PRL hyperresponse showed that alteration in DRD3 gene. Statistical analysis failed to demonstrate any significant difference between these frequencies, thus evidencing that this alteration does not seem to be associated with PRL hyperresponse after TRH stimulation.

Control group women showing the five-base deletion in the DRD3 gene showed significantly lower baseline values of PRL when compared to those without this polymorphism. However, this finding was not reproduced in the anovulatory group without hyperresponse of PRL nor in the control anovulatory women without PRL hyperresponse. Also, analyses performed on all women, including those demonstrating PRL hyperresponse after TRH stimulation, showed that baseline and peak PRL levels were significantly lower in those with DRD3 gene polymorphism. DRD3 gene 41563_42567delTAAGT polymorphism is not associated with anovulatory states.

On the other hand, further studies should investigate the role these DRD3 gene polymorphisms play on the individualization of treatment for infertile women's chronic anovulation caused by hyperprolactinemia with hyperactive agonists, specifically of dopaminergic receptors. Other embracing studies should be supportive of investigations regarding the DRD3 gene 41563_42567delTAAGT polymorphism, with DNA complementary sequencing and the study of DRD3 gene mRNA expression in peripheral blood lymphocytes, consistent with CNS representation and compatible with schizophrenia studies (Ilani et al., 2001).

Finally, after performing for the first time the complete analysis of DRD3 gene-coding region in chronic anovulatory women, we were able to find the already acknowledged DRD3 gene polymorphisms at positions 9 and 17 at a frequency similar to that reported in the international literature and in our control group. We also described for the first time, the 
41563_42567delTAAGT polymorphism which did not show any association with chronic anovulation. Further studies should be aimed at evaluating the importance these polymorphisms have in the individualization of treatment for female infertility caused by hyperprolactinemia with hyperactive agonists and dopaminergic-specific receptors as well as other genes likely to be involved in the pathogenesis of this disease.

\section{ACKNOWLEDGMENTS}

We are grateful to the Support Center for Scientific Publications of Santa Casa de São Paulo, Faculty of Medical Sciences, for editorial assistance.

\section{REFERENCES}

Andersen AN, Hagen C, Lange P, Boesgaard S, et al. (1987). Dopaminergic regulation of gonadotropin levels and pulsatility in normal women. Fertil. Steril. 47: 391-397.

Cavalli SA, Otta MI, Hirata RDC, Nguyen NY, et al. (1996). Apoliprotein E genotyping in Brasilian normolipemic individuals. Clin. Chem. 42: S298.

Cooper JR, Bloom FE and Roth HR (1991). The biochemical basis of neuropharmacology. University Press, New York.

DiMaio S, Grizenko N and Joober R (2003). Dopamine genes and attention-deficit hyperactivity disorder: a review. $J$. Psychiatry Neurosci. 28: 27-38.

Dubertret C, Gorwood P, Ades J, Feingold J, et al. (1998). Meta-analysis of DRD3 gene and schizophrenia: ethnic heterogeneity and significant association in Caucasians. Am. J. Med. Genet. 81: 318-322.

ESHRE Capri Workshop Group (1995). Anovulatory infertility. Hum. Reprod. 10: 1546-1553.

Fauser BC, Pache TD, Lamberts SW, Hop WC, et al. (1991). Serum bioactive and immunoreactive luteinizing hormone and follicle-stimulating hormone levels in women with cycle abnormalities, with or without polycystic ovarian disease. J. Clin. Endocrinol. Metab. 73: 811-817.

Fernandes MAS and Bahamondes L (1996). Incidência dos fatores etiológicos de esterilidade conjugal nos hospitais universitários de Campinas. Rev. Bras. Ginecol. Obstet. 18: 29-36.

Frey KA and Patel KS (2004). Initial evaluation and management of infertility by the primary care physician. Mayo Clin. Proc. 79: 1439-1443.

Ilani T, Ben-Shachar D, Strous RD, Mazor M, et al. (2001). A peripheral marker for schizophrenia: Increased levels of D3 dopamine receptor mRNA in blood lymphocytes. Proc. Natl. Acad. Sci U. S. A. 98: 625-628.

Ioannidis JP, Ntzani EE, Trikalinos TA and Contopoulos-Ioannidis DG (2001). Replication validity of genetic association studies. Nat. Genet. 29: 306-309.

Jonsson EG, Flyckt L, Burgert E, Crocq MA, et al. (2003). Dopamine D3 receptor gene Ser9Gly variant and schizophrenia: association study and meta-analysis. Psychiatr. Genet. 13: 1-12.

Jonsson EG, Kaiser R, Brockmoller J, Nimgaonkar VL, et al. (2004). Meta-analysis of the dopamine D3 receptor gene (DRD3) Ser9Gly variant and schizophrenia. Psychiatr. Genet. 14: 9-12.

Kahsar-Miller M, Boots LR and Azziz R (1999). Dopamine D3 receptor polymorphism is not associated with the polycystic ovary syndrome. Fertil. Steril. 71: 436-438.

Knoepfelmacher M (1988). Cálcio e secreção de prolactina em humanos: efeitos do bloqueador de canais de cálcio verapamil - na hiperprolactinemia espontânea e induzida. Doctoral thesis, Faculdade de Medicina da Universidade de São Paulo, São Paulo.

Lahiri DK and Nurnberger JI Jr (1991). A rapid non-enzymatic method for the preparation of HMW DNA from blood for RFLP studies. Nucleic Acids Res. 19: 5444.

Legro RS, Muhleman DR, Comings DE, Lobo RA, et al. (1995). A dopamine D3 receptor genotype is associated with hyperandrogenic chronic anovulation and resistant to ovulation induction with clomiphene citrate in female Hispanics. Fertil. Steril. 63: 779-784.

Mathé C, Sagot MF, Schiex T and Rouze P (2002). Current methods of gene prediction, their strengths and weaknesses. Nucleic Acids Res. 30: 4103-4117.

Moro M, Inada Y, Miyata H, Komatsu H, et al. (2001). Effects of dopamine d2 receptor agonists in a pituitary transplantationinduced hyperprolactinaemia/anovulation model in rats. Clin. Exp. Pharmacol. Physiol. 28: 651-658.

Genetics and Molecular Research 7 (1): 140-151 (2008) 
Muglia P, Jain U and Kennedy JL (2002). A transmission disequilibrium test of the Ser9/Gly dopamine D3 receptor gene polymorphism in adult attention-deficit hyperactivity disorder. Behav. Brain Res. 130: 91-95.

Pettersson-Fernholm KJ, Forsblom CM, Perola M, Fagerudd JA, et al. (2004). Dopamine D3 receptor gene polymorphisms, blood pressure and nephropathy in type 1 diabetic patients. Nephrol. Dial. Transplant. 19: 1432-1436.

Rasmussen DD, Liu JH, Wolf PL and Yen SS (1986). Gonadotropin-releasing hormone neurosecretion in the human hypothalamus: in vitro regulation by dopamine. J. Clin. Endocrinol. Metab. 62: 479-483.

Rice T, Rankinen T, Chagnon YC, Province MA, et al. (2002). Genomewide linkage scan of resting blood pressure: HERITAGE Family Study. Health, Risk Factors, Exercise Training, and Genetics. Hypertension 39: $1037-1043$.

Rybakowski JK, Borkowska A, Czerski PM and Hauser J (2001). Dopamine D3 receptor (DRD3) gene polymorphism is associated with the intensity of eye movement disturbances in schizophrenic patients and healthy subjects. Mol. Psychiatry 6: 718-724.

Salazar LA, Hirata MH, Cavalli SA, Machado MO, et al. (1998). Optimized procedure for DNA isolation from fresh and cryopreserved clotted human blood useful in clinical molecular testing. Clin. Chem. 44: 1748-1750.

Sekiva T (1993). Detection of mutant sequences by single-strand conformation polymorphism analysis. Mut. Res. 288: 79-83.

Sibley DR and Monsma FJ Jr (1992). Molecular biology of dopamine receptors. Trends Pharmacol. Sci. 13: 61-69.

Snyder EE and Stormo GD (1993). Identification of coding regions in genomic DNA sequences: an application of dynamic programming and neural networks. Nucleic Acids Res. 21: 607-613.

Sokoloff P, Giros B, Martres MP, Bouthenet ML, et al. (1990). Molecular cloning and characterization of a novel dopamine receptor (D3) as a target for neuroleptics. Nature 347: 146-151.

Speroff L, Glass RH and Kase NG (1999). Clinical gynecologic and infertility. Lippincott Williams \& Wilkins, New York, 487-521.

Staddon S, Arranz MJ, Mancama D, Perez-Nievas F, et al. (2005). Association between dopamine D3 receptor gene polymorphisms and schizophrenia in an isolate population. Schizophr. Res. 73: 49-54.

Taylor AE, McCourt B, Martin KA, Anderson EJ, et al. (1997). Determinants of abnormal gonadotropin secretion in clinically defined women with polycystic ovary syndrome. J. Clin. Endocrinol. Metab. 82: 2248-2256.

Verhelst J, Abs R, Maiter D, van den Bruel A, et al. (1999). Cabergoline in the treatment of hyperprolactinemia: a study in 455 patients. J. Clin. Endocrinol. Metab. 84: 2518-2522.

Williams J, Spurlock G, Holmans P, Mant R, et al. (1998). A meta-analysis and transmission disequilibrium study of association between the dopamine D3 receptor gene and schizophrenia. Mol. Psychiatry 3: 141-149.

Yen SSC (1979). Studies of the role of dopamine in the control of prolactin and gonadotropin secretion in humans. In: Central regulations of the endocrine system (Fluxe K, Hokfelt T and Lufts R, eds.). Plenum Press, New York, $387-441$.

Zhang ZJ, Zhang XB, Hou G, Yao H, et al. (2003). Interaction between polymorphisms of the dopamine D3 receptor and manganese superoxide dismutase genes in susceptibility to tardive dyskinesia. Psychiatr. Genet. 13: $187-192$. 